\title{
Introduction: Towards a Cognitive Theory of New Testament Characters: Methodology, Problems, and Desiderata
}

\author{
Jan Rüggemeier \\ Rheinische Friedrich-Wilhelms-Universität Bonn, Bonn, Germany \\ rueggemeier@uni-bonn.de \\ Elizabeth E. Shively \\ University of St Andrews, St Andrews, UK \\ ees3@st-andrews.ac.uk
}

\begin{abstract}
This Introduction provides an overview of a cognitive-narratological approach to characters and characterization in New Testament narratives. We begin by comparing conventional and cognitive approaches to New Testament characters and characterization, and delineating a practical methodology designed to sensitize readers to a variety of interpretative possibilities that arise from the cognitive turn within narratology. Afterwards, we apply that methodology in three ways. First, we acquaint readers with the prospect of tracing characters within one New Testament narrative. Then, we hint at the analysis of character migration, that is, a character's development across more than one narrative. Finally, we provide insight into the analysis of character emotions and the readers' empathy with characters. To illustrate these aspects, we focus on examples from the Gospel of Mark.
\end{abstract}

\section{Keywords}

(non-)cognitive approaches - characterization - character development - character migration - emotions 
The study of New Testament narratives has largely focused on the analysis of textual phenomena and their reader effects. The articles in this Special Issue use cognitive linguistics to explore how writers and their audiences perceive, process, and put into practice those textual phenomena. Thus, this Issue participates in the current vibrancy of postclassical narratology ${ }^{1}$ that pervades virtually all related academic disciplines, from cognitive narratology, ${ }^{2}$ to ancient history and classical studies ${ }^{3}$ to cultural science, ${ }^{4}$ and media studies. ${ }^{5}$ Altogether, our goal is to sensitize readers to the variety of possibilities that arise from the cognitive turn within narratology for interpreting New Testament narrative, and at the same time remove some existing prejudices to engaging in this sort of interdisciplinary research.

We as biblical scholars have been doing interdisciplinary work for fifty years by appropriating literary criticism; however, we have not fully kept up with its progress. Yet it is incumbent on us as those who use other disciplines to keep up so that we can theorize well. This is not to suggest that we use every new development; rather, it is to insist that we constantly test our theoretical claims and assess their implications. This is because, as literary theorist Patricia Kolaiti comments, "a discipline without a proper theoretical apparatus weakens [its] epistemic credibility and status ... as a domain of enquiry and significantly affects its interdisciplinary appeal." 6 The point is that unreflective use of literary theories for the study of New Testament narratives diminishes the plausibility of our interdisciplinary work.

1 G. Olson (ed.), Current Trends in Narratology (Narratologia, 27; Berlin: De Gruyter, 2011); M. Fludernik and J. Alber (eds.), Postclassical Narratology: Approaches and Analyses (Columbus: Ohio State University Press, 2010).

2 D. Herman, Storytelling and the Sciences of Mind (Cambridge: MIT Press, 2013). Idem, "Cognitive Narratology," in J.C. Meister (ed.), The Living Handbook of Narratology (Hamburg: Hamburg University Press; revised version uploaded 22 September 2013), https://www.lhn.unihamburg.de/node/38.html.

3 J. Grethlein et al. (eds.), Narratology and Interpretation. The Content of Narrative Form in Ancient Literature (Trends in Classics, Supplementary Volume 4; Berlin et al.: De Gruyter, 2009).

4 A. Nünning, "Towards a Cultural and Historical Narratology: A Survey of Diachronic Approaches, Concepts, and Research Projects," in B. Reitz and S. Rieuwerts (eds.), Proceedings of the Conference of German Association of University Teachers of English Vol. XXI (Mainz and Trier: WVT, 2000), pp. 345-373.

5 J. Eder, "Gottesdarstellung und Figurenanalyse. Methodologische Überlegungen aus medienwissenschaftlicher Perspektive," in U.E. Eisen and I. Müllner (eds.), Gott als Figur. Narratologische Analysen biblischer Texte und ihrer Adaptionen (Herders biblische Studien, 82; Freiburg: Herder, 2016), pp. 27-54.

6 P. Kolaiti, The Limits of Expression (Cambridge: Cambridge University Press, 2019), pp. 100-101. 
Thus it is sensible for us to notice that today's literary critics increasingly recognize that a single discipline is not adequate for addressing their own study of texts. Formalist and structuralist approaches have the benefit of laying bare a text; but analysis of the surface level of the text alone cannot adequately account for the activity of writers and readers, or their contexts. With the postmodern turn, new historicist and new formalist theories have challenged the view that narratives are autonomous, closed systems by insisting on the importance of their historical, cultural, and ideological situatedness. Yet these movements are unable to explain how real readers decide what elements in a narrative are valid or relevant at all, how they use the extratextual information they access, or how they respond to characters on a mental and emotional level.

To address such shortcomings, literary critics have turned to the cognitive disciplines as the most suitable and promising way forward. ${ }^{7}$ This is because literary phenomena are primarily engaged with cognitive domains such as language, memory, emotions, and anticipation/planning. ${ }^{8}$ As a result, the cognitive disciplines can help to account for these domains in literature in ways that traditional narratological analysis cannot. Still, some may think it implausible to use modern theories for analyzing ancient text corpora; however, the fact that cognitive science is biology-based rather than culture-based gives it a universal relevance. ${ }^{9}$ That is, a cognitive approach does not simply provide another way among many of looking at texts, but allows us to bring current, scientific knowledge about the way people think to bear upon our varied research.

7 On the emergence and development of the "cognitive turn" in literature, see L. Zunshine (ed.), The Oxford Handbook of Cognitive Literary Studies (Oxford: Oxford University Press, 2017); A. Müller-Wood, "Cognitive Literary Studies: On Persistent Problems and Plausible Solutions," Journal of Literary Theory 11 (2017), pp. 222-239; D. Herman (ed.), The Emergence of Mind: Representations of Consciousness in Narrative Discourse in English (Lincoln: University of Nebraska Press, 2011); M. Fludernik, "Narratology in the Twenty-First Century: The Cognitive Approach to Narrative," Special Topic: Literary Criticism for the Twenty-First Century. PLMA 125 (2010), pp. 924-930; M. Turner, "The Cognitive Study of Art, Language, and Literature," Poetics Today 23 (2002), pp. 9-20.

8 Kolaiti, The Limits of Expression, p. 101.

9 For further discussion, see M.R. Whitenton, Configuring Nicodemus: An Interdisciplinary Approach to Complex Characterization (London: T\&T Clark, 2019), pp. 11-54; G. Steen, "Genre between the Humanities and the Sciences," in M. Callies, W.R. Keller, and A. Lohöfer (eds.), Bi-Directionality in the Cognitive Sciences: Avenues, Challenges, and Limitations (Human Cognitive Processing, 30; Amsterdam and Philadelphia: John Benjamins, 2011), pp. 21-42. 
In particular, literary theorists have been drawing on the cognitive disciplines to interpret characters for thirty years. ${ }^{10}$ John Darr was one of the first biblical scholars to recognize the benefit of drawing on cognitive science to account for readers in character construction. He explains characterization as "a temporal, cognitive activity that involves the processing of textual and extratextual data" and therefore "is a series of mental 'moves' constrained by text and extratext."1 That is, characters are not simply "in" the text; rather, characters are both communicated and constructed. Many NT scholars recruit Darr's work without developing the interdisciplinary, theoretical ideas that underpin it. More recently, however, a growing number of studies on New Testament narrative have analyzed characters from a cognitive perspective, ${ }^{12}$ and we seek to take forward this impulse.

This attention to characters and characterization in New Testament narratives is a natural choice because character analysis has been a focal point of the study of New Testament narratives since the literary turn reached biblical studies in the 1970s. ${ }^{13}$ Structuralist narratology, at that time, tended to subordinate

10 F. Jannidis, "Character," in P. Hühn et al. (eds.), Handbook of Narratology 1 (Berlin: De Gruyter, 2014), p. 31-32; J. Eder, Die Figur im Film. Grundlagen der Figurenanalyse (Marburg: Schüren, 2008); J. Culpeper, "A Cognitive Stylistic Approach to Characterisation," in E. Semino and J. Culpeper (eds.), Cognitive Stylistics (Amsterdam and Philadelphia: Benjamins, 2002), pp. 251-277; R. Schneider, Grundriß zur kognitiven Theorie der Figurenkonzeption am Beispiel des viktorianischen Romans, (ZAA Studies, 9; Tübingen: Stauffenburg, 2000); The pioneering work of Margolin on characters led to the adoption of possible worlds theory, cognitive theories, and neuro-hermeneutics in literary criticism.

11 J.A. Darr, "Narrator as Character: Mapping a Reader-Oriented Approach to Narration in LukeActs," Semeia (1993), pp. 43-6o (50). Idem, On Character Building: The Reader and the Rhetoric of Characterization in Luke-Acts (Louisville: Westminster and John Knox Press, 1992).

For example, E.E. Shively, "Becoming a Disciple without Seeing Jesus: Narrative as a Way of Knowing in Mark's Gospel," in E.K. Broadhead (ed.), Let the Reader Understand: Studies in Honor of Elizabeth Struthers Malbon (New York: Bloomsbury and T\&T Clark, 2018), pp. 35-5o; J. Rüggemeier, Poetik der markinischen Christologie. Eine kognitiv-narratologische Exegese (wunT, 2/458; Tübingen: Mohr Siebeck, 2017); M.R. Whitenton, Hearing Kyriotic Sonship. A Cognitive and Rhetorical Approach to the Characterization of Mark's Jesus (BibInt, 148; Leiden and Boston, MA: Brill 2016); K.M. Hartvigsen, Prepare the Way of the Lord: Towards a Cognitive Poetic Analysis of Audience Involvement with Characters and Events in the Markan World (BZNW, 180; Berlin: De Gruyter, 2012); S. Finnern, Narratologie und Biblische Exegese. Eine integrative Methode der Erzählanalyse und ihr Ertrag am Beispiel von Matthäus 28 (wUnT, 2/285; Tübingen: Mohr Siebeck, 2010), pp. 125-164, 325-365.

13 Taking the study of the Gospel of Mark as an example, see C.W. Skinner, "The Study of Character(s) in the Gospel of Mark: A Survey of Research from Wrede to the Performance Critics (1901-2014)," in C.W. Skinner and M.R. Hauge (eds.), Character Studies and the Gospel of Mark, (LNTS, 473; London: Bloomsbury and T\&T Clark, 2014), pp. 3-34; and W.R. Telford, Writing on the Gospel of Mark (Guides to Advanced Biblical Research; Dorset: Deo Publishing, 2009), pp. 392-403, lists 269 entries on characters. 
character to plot; ${ }^{14}$ however, literary critic Seymour Chatman uncharacteristically insisted that "plot and character are equally important."15 Biblical scholars who developed narrative criticism followed Chatman's lead. ${ }^{16}$ For example, the pioneering book, Mark as Story, states that "characters are agents in a plot" and "the actions of the plot are expressions of the characters." ${ }^{27}$ Subsequent definitions of character reflected this symbiotic relationship. ${ }^{18}$ Moreover, in a programmatic 1977 article, Robert Tannehill set the foundation for later Gospels scholars to attend to the dynamics of character construction. ${ }^{19}$ Tannehill built upon the assumption that the Gospel of Mark is a unified story to investigate "the function of the disciples in the implicit dialogue between author and reader." ${ }^{20} \mathrm{He}$ argued that the author shapes the presentation of the disciples in such a way as to elicit a certain response from the reader in the process of

14 This neglect has been criticized by F. Jannidis, Figur und Person: Beitrag zu einer historischen Narratologie (Berlin et al.: De Gruyter, 2004), pp. 1-5. For a similar critique, see A. Culpepper, Anatomy of the Fourth Gospel: A Study in Literary Design (Minneapolis: Fortress Press, 1983), p. 101.

15 S. Chatman, Story and Discourse: Narrative Structure in Fiction and Film (Ithaca: Cornell University Press, 1978), p. 110. Exceptions to this include J.L. Resseguie, Narrative Criticism of the New Testament: An Introduction (Grand Rapids: Baker, 2005), who follows a supposedly Aristotelian view and defines all characters as flat or static types that follow the conventions of ancient literature. For an argument against the view that biblical narratives follow such conventions in their portrayal of characters, see R. Scholes and R. Kellogg, The Nature of Narrative (Oxford: Oxford University Press, 1966), pp. 164-165; and A. Berlin, Poetics and Interpretation of Biblical Narrative (Sheffield: Almond Press, 1983), pp. 37-38.

16 The most influential early book-length works of New Testament narrative criticism followed Chatman, including D.M. Rhoads and D. Michie, Mark as Story: The Introduction to the Narrative of a Gospel (Philadelphia: Fortress Press, 1982); Culpepper, Anatomy; R.A. Edwards, Matthew's Story of Jesus (Philadelphia: Fortress Press, 1985); J.D. Kingsbury, Matthew as Story (Minneapolis: Fortress Press, 2nd edn, 1988); R.C. Tannehill, The Narrative Unity of Luke-Acts: A Literary Interpretation, Vol. 1 (Philadelphia: Fortress Press, 1986).

17 David Rhoads, Joanna Dewey, and Donald Michie, Mark as Story: An Introduction to the Narrative of a Gospel (Minneapolis: Fortress Press, 3rd edn, 2012), 208.

18 M.A. Powell, What is Narrative Criticism?, gbs (Minneapolis: Fortress Press, 1993), p. 51; E. Struthers Malbon, "Narrative Criticism: How Does the Story Mean?" in J.C. Anderson and S.D. Moore (eds.), Mark \& Method: New Approaches in Biblical Studies (Minneapolis: Fortress Press, 2nd edn, 2008), pp. 29-58 (9).

19 R.C. Tannehill, "The Disciples in Mark: The Function of a Narrative Role," JR 57 (1977), pp. 386-405. See the development of character construction/building in, for example, F. Burnett, "Characterization and Reader Construction of Characters in the Gospels," Semeia 63 (1993): 3-78; D. Gowler, Host, Guest, Enemy, and Friend (Emory Studies in Early Christianity 2; New York: Peter Lang, 1991); J. Darr, On Character Building: The Reader and the Rhetoric of Characterization in Luke-Acts (Louisville: Westminster/John Knox Press, 1992); idem, Herod the Fox: Audience Criticism and Lukan Characterization (Sheffield: Sheffield Academic Press, 1998).

Tannehill, “Disciples," 386. 
reading the story. In what follows, we take forward this focus on characters by using research in the cognitive disciplines to show that character construction is more dynamic than literary currents in New Testament studies has allowed. Yet two challenges immediately face those who wish to use recent, extradisciplinary approaches like cognitive linguistics to aid in the interpretation of ancient text corpora like the New Testament: One is to justify their use. The other is to use them well.

From the variety of possible approaches, we select those that have hardly been taken into account in New Testament studies so far, and which at the same time seem particularly promising for the investigation of New Testament characters and their peculiarities. After relating and contrasting non-cognitive and cognitive-narrative approaches to (1) characters and characterization, we will deal with the aspects of (2) character development, (3) character migration, (4) character emotions, and the reader's ability to empathize with characters. The first aspect draws attention to ancient authors already expecting their readers to keep earlier characterizations in mind and to be able to recall this character-related information as the narrative progresses. ${ }^{21}$ The aspect of character migration raises awareness that characters remain recognizable across different gospels and in non-canonical narratives and that this is possible without direct literary dependencies. The third aspect addresses commonly articulated concerns that arise in the study of character emotions (e.g., psychologism, subjectivism) and shows how a cognitive-linguistic approach can contribute to a more nuanced and methodologically controlled analysis.

For illustration of these three aspects we focus on the Gospel of Mark. Our contributors then branch into other texts and cognitive linguistic approaches to continue where we leave off. ${ }^{22}$

\section{Non-Cognitive Approaches to Characters and Characterization in New Testament Narratives}

On a basic level, all biblical scholars, no matter their approach, understand New Testament characters to be human-like. Views of that human-likeness,

21 For examples of such character development in ancient literature, see M. Tröster, Themes, Character, and Politics in Plutarch's Life of Lucullus: The Construction of a Roman Aristocrat (Stuttgart: Steiner, 2008), p. 52; T.E. Duff, "Plutarch on the Childhood of Alkibiades (Alk. 2-3)," PCPhS 49 (2003), pp. 89-117.

22 A synopsis of each contribution appears at the end of this article. 
however, generally follow a conventional split among literary critics: $\left.{ }^{23} 1\right)$ historical criticism and New Historicism view characters as mimetic, that is, as referring to real people in the world; 2) narrative criticism, structuralism and post-structuralism view characters as nonmimetic, that is, as a paradigm of traits based on words within the story. ${ }^{24}$

Curiously, biblical scholars of both the mimetic and non-mimetic viewpoints tend to adopt a text-internal approach to characterization. ${ }^{25}$ Characterization has been conventionally understood as a process by which the implied author or narrator ascribes psychological or social traits to a character. Narrative criticism, like classical narratology, thus views characterization as a text-internal event, that is, as a process that moves in the direction from implied author or narrator to implied reader. ${ }^{26}$ As Elizabeth Struthers Malbon states, "characters are brought to life for the implied reader or narrator by the implied author through narrating words and actions." ${ }^{27}$ That is, the implied author or narrator communicates character traits through a character's own words and actions; through those of another character; or through the narrators' words and rhetorical actions as the plot develops. ${ }^{28}$ Through an accumulation of such words and actions in the narrative, the implied audience forms impressions of, identifies with (sympathy, empathy, or antipathy), and makes judgments about (responds positively or negatively to) characters. ${ }^{29}$ Identification with and judgments of characters are involved in characterization; but since the implied author and implied reader are textual constructs, characterization

23 Jannidis, "Character," p. 32. See also M.B. Dinkler, Literary Theory and the New Testament (Anchor Yale Bible Reference Series; New Haven and London: Yale University Press, 2019), p. 156, who distinguishes between "referential" and "nonmimetic".

24 Rhoads, Dewey, and Michie, Mark as Story, p. 103; Powell, What is Narrative Criticism, p. 51; Chatman, Story and Discourse, pp. 127-132; Mieke Bal, Narratology: Introduction to the Theory of Narrative (Toronto: University of Toronto Press, 4th edn, 2018), pp. 126-127.

25 Mark Allan Powell has observed that NT scholars may employ narrative criticism with either an author-centered, text-centered, or reader-centered hermeneutic; however, "[t]he basic goal of narrative criticism is to discern how the implied reader of a narrative would be expected to respond [by the implied author] to the text." M.A. Powell, "Narrative Criticism: The Emergence of a Prominent Reading Strategy," in K.R. Iverson and C.R. Skinner (eds.), Mark as Story: Retrospect and Prospect (SBLRBS, 65; Atlanta: SBL, 2011), pp. 22-23.

26 Jannidis, "Character," p. 31.

27 Malbon, "Narrative Criticism," p. 29. See also E.S. Malbon, Mark's Jesus: Characterization as Narrative Christology (Waco: Baylor University Press, 2009), p. 8.

28 Malbon, "Narrative Criticism," p. 9; Rhoads, Dewey, and Michie, Mark as Story, p. 105.

29 Rhoads, Dewey, and Michie, Mark as Story, pp. 99, 103; Malbon, Narrative Criticism, 9. See this approach applied in D. Wenham and S. Walton, Exploring the New Testament. Vol. 1: The Gospels and Acts (London: SPCK, 3rd edn, 2020), pp. 98-99; and J. Brown, The Gospels as Stories, pp. $72-73$. 
is a text-internal process. This is true even of reader-oriented developments in narrative criticism, which have appropriated reader-response criticism in largely formalist terms. ${ }^{30}$ For example, Mark as Story exhibits a shift towards a reader-oriented hermeneutic in its second and third editions. ${ }^{31}$ Yet the authors focus their attention on elements internal to a narrative, examining how a narrator seeks to shape ideal, implied audiences and elicit responses from them by means of a story's rhetoric.

Yet the dogged privileging of the implied author's or narrator's role in character construction to which an implied reader responds creates a disembodied reading process that does not fully account for the role of real authors and real readers in character construction. As a result, any understanding of characters' "human-like" qualities remains split between the real-world referent on one side of a chasm and the function of its linguistic or formal system on the other. ${ }^{32}$

Historically informed literary approaches have sought to address the disembodied reading process by contextualizing narrative analysis, thereby merging the historical-narratological world of the text with the contemporary world of readers. Even attention to characters as a historically informed paradigm of traits, however, tends to focus on formal elements without fully accounting for the variety of human-like properties (i.e., mental, physiological, emotional, spatial) by which various readers understand and respond to characters, or for how readers perceive or respond to characters at all. While historical and literary approaches provide us with necessary cultural, linguistic, textual, and rhetorical tools for describing characters, what we need is an accompanying

30 In contemporary literary theory, reader-response criticism developed as a response to New Criticism's treatment of the text as a closed system which eclipsed the reader. See W. Iser, The Act of Reading: A Theory of Aesthetic Response (Baltimore: Johns Hopkins University Press, 1978); S. Fish, Is There a Text in This Class: The Authority of Interpretive Communities (Cambridge: Harvard University Press, 1980). Introduced to NT studies by R.C. Tannehill in formalist terms in, "The Disciples in Mark: The Function of a Narrative Role," JR 57 (1977), pp. 386-405. R.M. Fowler developed it as a critique of narrative criticism in Let the Reader Understand: Reader-Response Criticism and the Gospel of Mark (Harrisburg: Trinity Press International, 2001).

31 Rhoads, Dewey, and Michie, Mark as Story, (Minneapolis: Fortress Press, 2nd edn, 1999); Rhoads Dewey, and Michie, Mark as Story. See also D.M. Rhoads, Reading Mark: Engaging the Gospel (Minneapolis: Fortress Press, 2004), pp. 31-32.

32 A number of studies integrate historical and literary methods and prominently address characters and characterization, including J. Brown, The Gospels as Stories, pp. 63-104; M.B. Dinkler, Literary Theory, pp. 149-153; C. Bennema, A Theory of Character in New Testament Narrative. A Proposed Paradigm for Character Reconstruction (Minneapolis: Fortress Press, 2014); P. Merenlahti, Poetics for the Gospels? Rethinking Narrative Criticism (Studies of the New Testament and Its World; Edinburgh: T\&T Clark, 2002), pp. 77-98. 
cognitive model to explain the complex mental and emotional processing involved in characterization.

\section{A Cognitive-Narratological Approach to Narrative Texts, Characters and Characterization}

Cognitive linguistics enables the expansion of a narratological approach by which to view narrative texts and their elements as simultaneously communicated by actual authors and constructed by actual readers. Specifically, cognitive narratology views characters as mental models of persons-in-a-world, ${ }^{33}$ and characterization as the process by which readers build mental models in the course of reading a text.

Mental models are hypothetical cognitive images, or "bundles of information" 34 held in memory. When we initially encounter an activity, situation, text, etc., its features activate mental models that serve as "recipes for generating organizational structures in a particular task context." ${ }^{35}$ Mental models have a number features or "slots" populated by prototypical inputs based on prior knowledge and experience. ${ }^{36}$ Crucially, then, mental models are embedded in culture and generated by situations. ${ }^{37}$ Yet while an initial encounter with a text or a character, for example, activates a mental model by which to understand

33 R. Schneider, "Toward a Cognitive Theory of Literary Character. The Dynamics of MentalModel Construction," Style 35 (2001), pp. 607-640 (607). Narrative texts are also mental models constructed in the process of reading. W. Kintsch, Comprehension: A Paradigm for Cognition (Cambridge: Cambridge University Press, 1998).

34 P. Stockwell, Cognitive Poetics: An Introduction (2nd edn London and New York: Routledge, 2020), p. 21.

35 Kintsch, Comprehension, p. 37.

36 Eleanor Rosch's pioneering work overturned the classical idea of categories by developing the idea that people conceptualize prototypes and then see other members of the category in relation to the prototype. See E. Rosch, "Cognitive Representations of Semantic Categories," Journal of Experimental Psychology: General 104 (1975), pp. 192-233; see esp. 193; and E. Rosch and B.B. Lloyd (eds.), Cognition and Categorization (Hillsdale: Lawrence Erlbaum, 1978).

37 "One cannot have symbolic thought in an individual mind, only in a mind that is part of a certain culture." Kintsch, Comprehension, p. 29. See also William A. Johnson, "reading is not simply the cognitive process by the individual of the 'technology' of writing, but rather the negotiated construction of meaning within a particular sociocultural context." William A. Johnson, Readers and Reading Culture in the High Roman Empire: A Study of Elite Communities (ccs; New York: Oxford University Press, 2010), p. 6o3; cf. p. 9. Here, Johnson contrasts the individual cognitive process of reading with the social event level of meaningconstruction. In our view, however, the social and cognitive dimensions of reading are not easily disentangled. 
it at a specific point ("top down" processing), a reader's encounter with new information in real time generates modifications of that mental model ("bottom up" processing). ${ }^{38}$ Thus, the dynamic process of building mental models enables readers to recognize, explain, categorize, and use concepts in textual contexts through comparison, contrast, and modification of what they know.

Key sources of input for mental models of characters include the following: ${ }^{39}$

a. Explicit and implicit textual cues. This is a legacy of narrative criticism and narratology. 40

b. Mental model of persons. ${ }^{41}$ Once actual readers recognize a character as human-like, they categorize the character as a "person." According to this mental model, a character's mind has the same sorts of structures as human minds: knowledge, language, emotion, motivation, perception, planning, the capability to make inferences, and so on. As a result, a reader may ascribe to a character various properties that includes not only material features but also intentions and mental and emotional capacities. ${ }^{42}$

c. Cultural frames and scripts. These are kinds of mental models that encompass the social and cultural knowledge of actual readers. A cultural frame is general, prototypical knowledge of a concept, while a cultural script is stereotypical knowledge of an action sequence. First, readers may have a certain prototypical idea ${ }^{43}$ of a synagogue, ${ }^{44}$ a wild animal, a New Yorker,

38 See W. Kintsch, "An Overview of Top-Down and Bottom-Up Effects in Comprehension: The ci Perspective," Discourse Processes 39 (2005), pp. 125-128. The "top down" processing inherent to schemata is expressed in R.C. Schank and R.P. Abelson, Scripts, Plans, Goals and Understanding: Inquiry into Human Knowledge Structures (Hillsdale, N.J., 1977). A model of "bottom up" processing was developed by W. Kintsch and T.A. van Dijk in "Toward a Model of Text Comprehension and Production," Logical Review, 85 (1978), and later presented in Kintsch, Comprehension.

39 Kintsch explains that for texts, "Typically...the mental text representation is a mixture of text-derived and knowledge-derived information, not necessarily in equal parts." Kintsch, Comprehension, 105; see also 119-120.

40 Herman, Storytelling, p. 44, 195.

41 Herman, Storytelling, p. 193.

42 Herman, Storytelling, p. 193; L. Zunshine, Why We Read Fiction: Theory of Mind and the Novel (Columbus: Ohio State University Press, 2006), pp. 22-27; Jannidis, Figur, pp. 185-195.

43 Cf. J. Aitchison, Words in the Mind. An Introduction to the Mental Lexicon (Oxford, UK: Blackwell, 1987); P. Stockwell, Cognitive Poetics, pp. 27-40.

44 As has been argued by Runesson, Binder, and Olson, the term "synagogue" was still fluid in the first century and did not yet refer to a specific building form. See A. Runesson, D.D. Binder, and B. Olson, The Ancient Synagogue from Its Origins to 200 C.E.: A Source Book (Ancient Judaism and Early Christianity, 72; Leiden and Boston: Brill, 2010), pp. 11-12. 
or a Galilean. ${ }^{45}$ As discussed above, prototypical knowledge allows readers to fill in "slots" in a "top down" way by applying general characteristics of what they "know" that place, animal, or person to be like; but through an encounter in real time, for example, with actual persons in a social situation or with characters in a text, readers also process and integrate new information in a "bottom up" way to update the mental model. Thus, mental models do not remain static, but become dynamic structures generated by and adapted for the situations in which readers use them. ${ }^{46}$

Second, readers draw on scripts, small spatial stories in which we put events with agents in sequence. Scripts are mental models that represent the narrative imagining we use to make sense of everyday experiences. For example, the script "picking up a ball and throwing it" helps us to predict what will happen and plan our response not only when if someone picks up a baseball and cocks their arm, but also when they pick up other objects, like car keys, with the same stance. Similarly, the situational script "digging a hole through a surface" provides the mental model for explaining and predicting the outcome of the scene in Mark 2:4, in which a group breaks up a roof to lower their friend to Jesus. Or, a personal script such as "observing purity rules" may provide the mental model for explaining and predicting the outcome of the priest's encounter with the half dead man in Luke 10:31. ${ }^{47}$ By analogy, one could also speak of historical scripts if readers are already familiar with historical persons and processes. When mentioned or implicitly referred to in the text, all these different cultural frames and scripts are activated during the reading process such that they are recalled, intensified or modified by other descriptions.

Based on the cognitive-narratological approach delineated above, we discuss in more detail what is involved in building mental models of characters, or characterization. ${ }^{48}$ As Ralf Schneider explains, characterization "happens through a complex interaction of what the text says about the characters and

45 Frames and scripts are formed through one's own life-world experience, literature and media consumption or even gossip (cf. Mark 6:14-29: popular idea of a "king" transferred to Herod).

46 Kintsch, Comprehension, 37.

47 For this famous differentiation between various kinds of scripts, see Schank and Abelson, Scripts, pp. 61-66.

48 K. Kukkonen, Probability Designs: Literature and Predictive Processing, Cognition and Poetics (Oxford: Oxford University Press, 2020); Herman, Storytelling, pp. 101-215; For the application of mental processing to NT characterization, see Rüggemeier, Poetik; Shively, "Becoming a Disciple." 
what the reader knows about the world in general, specifically about people and, yet more specifically, about 'people' in literature." 49 Thus, we may understand characterization as the actual reader's ascription of properties to characters in the course of reading or hearing a text in within a historical and cultural context, in order to construct mental models of persons-in-a-world. ${ }^{50}$

Schneider explains how actual readers engage in both "top down" and "bottom up" processing as they progressively work through narratives and interact simultaneously with textual and mental structures. ${ }^{51}$ When an actual reader initially encounters a character in a narrative, they fit that character into an existing category according to prototypical ideas in a "top down" sort of way. ${ }^{52}$ That is, initial textual cues evoke categories, or mental models. Using Mark's prologue as an example, these mental models may be social (Jesus as "Messiah"; John as "prophet"), literary (Jesus as Divine Warrior; John as Elijah), or text-specific (the Syro-Phoenician woman as an exemplary disciple). Yet they are shaped not only by textual cues, but also by actual readers' models of persons and by social and cultural frames. Thus, an actual first century Jewish reader may construct a different initial schema of Jesus or John that is closer to that of Mark's intended audience; which may be different than the initial mental model of an actual first century Roman reader ... or than that of any twenty-first century reader.

As actual readers continue to progress through the narrative, they also engage in a "bottom up" process to integrate textual information into the existing mental model. ${ }^{53}$ They may find that new textual information either confirms or conflicts with the initial mental model of a character. If they are unable to integrate new information about the character into the mental model, then they may change their categorization or revise their understanding. Every time we read texts we perform this sort of cognitive processing without even realizing it, to build the sort of coherent and cohesive structures (in this case, stories) required for comprehension. ${ }^{54}$

49 Schneider, "Cognitive Theory," p. 608.

$50 \quad J a n n i d i s$, "Character," p. 34; U. Margolin, "Character", in D. Herman (ed.), The Cambridge Companion to Narrative (Cambridge: Cambridge University Press, 2nd edn, 2014), pp. 30-45 (76); Herman, Storytelling, p. 192.

$5^{1}$ According to Schneider, "Top-down and bottom-up processing continually interact in the reading process on all levels: from the decoding of the graphic signs to the understanding of words, sentence structure and the contents of longer sections." Schneider, "Cognitive Theory," p. 611.

$5^{2}$ Schneider comments that a "reader's pre-stored knowledge structures are directly activated to incorporate new items of information." Schneider, Cognitive Theory," p. 610.

53 Schneider, "Cognitive Theory," p. 611: "bits of textual information are kept in working memory separately and integrated into an overall representation at a later point in time."

54 W. Kintsch, Comprehension: A Paradigm for Cognition (Cambridge: Cambridge University Press, 1998), p. 105. For a discussion of how ancient readers perceived textual cohesion and 
In sum, a cognitive approach is interested in how readers construct characters by processing textual phenomena and recruiting social and cultural knowledge (pre-existing cognitive frames and scripts). Yet an interest in how real readers construct characters does not eclipse real authors, but requires them. ${ }^{55}$ From a cognitive standpoint, the historical, writing author has a mental model of their intended addressees ${ }^{56}$ and conveys cues that enable real recipients to construct the intended mental model of the text, including its characters. ${ }^{57}$ The historical author thus plays a crucial role in the audience's construction of the mental models of characters through the orchestration of the textual phenomena. Textual cues suggest mental models that help readers organize what they encounter ("top down" processing); but then as readers read in real time, they hold textual elements in working memory and integrate one element with the next ("bottom up" processing). ${ }^{58}$ Readers refine and revise their mental model of texts by drawing on prior textual and social knowledge to fill gaps and indeterminacies. ${ }^{59}$ And if new textual elements conflict with readers' mental model of a character, they will either refine and incorporate those elements into and update that mental model, or discard it for another. Thus,

coherence, see M.A. Lyons, "Standards of Cohesion and Coherence: Evidence from Early Readers," in Hebrew Bible and Ancient Israel 9 (2020), pp. 183-208.

55 Jörg Schönert, "Author," in Peter Hühn, Jan Christoph Meister, John Pier, and Wolf Schmid (eds.), The Handbook of Narratology (Berlin, Munich, and Boston: De Gruyter, 2nd edn, 2014), views cognitive narratology's interest in cognitive processing as development of the opposition between the authorial intention and readerly meaning-making (pp. 8-9).

$5^{6}$ The intended addressees are the author's mental model of the specific, hypothetical group of readers/hearers/recipients for whom the author writes rhetorically, using various textual resources. See Finnern's concept of an intended reader (cf. Finnern, Narratologie, p. 52). This corresponds to Shively's concept of the authorial audience (cf. Shively, "Intentionality," pp. 327-329)

57 Sandra Heinen comments, "Texte sind intentionale Gebilde. Dies ist die Grundannahme, die jeder Interpretation vorausgeht" "Texts are intentional structures. This is the basic assumption that any interpretation precedes"). S. Heinen, "Das Bild des Autors. Überlegungen zum Begriff des ,impliziten Autors" und seines Potentials zur kulturwissenschaftlichen Beschreibung von inszenierter Autorschaft," Sprachkunst 33 (2002), pp. 329-345 (334). For a discussion of narrative texts as intentional systems, see E.E. Shively, "Intentionality and Narrative Worldmaking in the Gospel of Mark: Rethinking Narrative Communication," n G. Van Oyen (ed.). Reading the Gospel of Mark in the Twenty-First Century: Method and Meaning (BETL 301. Leuven: Leuven University Press/Peeters, 2019), 343-394," 312-313, 323-324.

58 See Kintsch, Comprehension, 101. See also Meir Sternberg, who addresses gap-filling in the process of reading Hebrew biblical narrative in, The Poetics of Biblical Narrative: Ideological Literature and the Drama of Reading (Bloomington: Indiana University Press, 1987), 186-229.

59 See further W. Iser, "The Reading Process: A Phenomenological Approach," New Literary History 3.2 (1972), pp. 279-299; idem, The Act of Reading: A Theory of Aesthetic Response (Baltimore: Johns Hopkins University Press, 1978), 110-113, 163-179. 
cognitive narratology presumes a communication model that unites the historical author, readers/audiences, texts, and contexts. None of these elements alone determines meaning; instead, meaning-making is a complex process of production, reception, and interpretation involving text-internal and text-external phenomena. As a result, a cognitive approach, not only enables but also requires a historical-culturally oriented literary study of NT narratives. ${ }^{60}$

\section{Character Development: Tracing Characters within One New Testament Narrative}

The Gospel of Mark provides a case study for expanding an aspect of characterization that has already received quite a bit of attention: character development within a single narrative. Mark's Jesus is perennially viewed as an enigmatic figure concealed by a riddling author. ${ }^{61}$ There is an obvious element of mystery to Mark's narrative; however, there is no reason to view this mysteriousness as antithetical to Mark's communicative intent or the readers' comprehension. To the contrary, a cognitive approach suggests that Mark is less ambiguous in his presentation of Jesus than is commonly thought.

For example, in the opening verses of the Gospel, Mark provides a script by announcing Archè̀ toũ Iēsoũ Christoũ huioũ theoũ (1:1). ${ }^{62}$ To take the role of the intended audience, today's actual readers must first recognize the various cultural frames that could have informed prototypical ideas of Mark and his actual ancient readers. Input from Greek and Roman traditions would have included Roman imperial discourse ${ }^{63}$ or divine man traditions. ${ }^{64}$ On the other hand, input from Jewish traditions would have included Israel's scriptures and traditions. ${ }^{65}$ Thus, for example, actual ancient audience members processing

6o Ansgar Nünning, "Towards a Cultural and Historical Narratology. A Survey of Diachronic Approaches, Concepts, and Research Projects," in B. Reitz and S. Rieuwertz (eds.), Anglistentag 1999 Mainz. Proceedings (Trier: wVT, 200o), pp. 345-373 (357). See also Heinen, "Das Bild des Autors," p. 340.

61 T.J. Geddert, "The Implied Yhwh Christology of Mark's Gospel: Mark's Challenge to the Reader to 'Connect the Dots,'” Bulletin for Biblical Research 25 (2015), pp. 325-340 (esp. 327).

62 This follows the longer version of Mark 1:1. See T. Wasserman, "The 'Son of God' Was in the Beginning (Mark 1:1)," JTS 62 (2011), pp. 20-50.

63 M. Lau, Der gekreuzigte Triumphator. Eine motivkritische Studie zum Markusevangelium (NTOA 114; Göttingen: Vandenhoeck \& Ruprecht, 2019), esp. pp. 444-454.

64 A.Yarbro Collins, "Mark and His Readers: The Son of God among Greeks and Romans," HTR 93 (2000), pp. 85-100 (100).

65 A.Yarbro Collins, "Mark and His Readers: The Son of God among Jews," HTR 92 (1999), pp. 393-408 (408). 
Mark's narrative would have made a distinct initial "top down" categorization from prototypical ideas of "Son of God," which may have been as varied as emperor, philosopher, miracle worker, or God's chosen and appointed one.

Significantly, however, Mark himself provides a frame by interpreting the opening script according to Israel's scriptures (1:2-3; Isa 40:3, Exod 23:20; Mal 3:1). Mark correlates the "good news" of Jesus' coming as Messiah and Son of God with Isaiah's "good news" of Yhwh's coming as Divine warrior to redeem Israel (1:6-7; Isa 40:9-10); then begins to fill out the script by confirming the man Jesus as the anointed Son of God and chosen Servant in whom God places his Spirit (Ps 2:7 and Isa 42:1 in Mark 1:11). Thus, while it is possible that Mark intends to communicate an implicit challenge against Rome, textual cues draw the intended audience and actual readers to confirm or modify their initial "top down" categorization along the lines of Israel's scripture and tradition as they perform "bottom up" processing.

Moreover, the primacy effect suggests that readers' opening encounter with Jesus facilitates the initial mental model into which subsequent textual information is integrated. ${ }^{66}$ As actual readers progressively process the rest of the narrative, the unfolding text activates various other character frames (e.g., son of man, lord, shepherd, teacher and prophet, righteous sufferer), the textual expectations of which they fill according to varied cultural frames. Mark presses readers to evaluate these frames - to reject or refine them, or to accept and incorporate them into the initial character model - through the arrangement of the narrative and scriptural elements. Two examples illustrate this point. First, when Peter confesses that Jesus is "Messiah" (v. 29), Jesus himself develops the interpretation of "Messiah" by predicting that the "Son of Man" will suffer, die, and rise according to scripture (v. 31; 9:12; 14:49). ${ }^{67}$ The use of the phrase "Son of Man" in conjunction with suffering and death conveys a paradox in the model of "Messiah" that develops the opening script (see also 10:45). Second, when readers progressively processing the text come to the Passion Narrative, Mark's use of Psalms of Lament do not now introduce a righteous sufferer character model that replaces the Isaianic Servant; one ${ }^{68}$ rather, this develops the profile of Jesus as the Suffering, Davidic Servant (recall

66 According to Monika Fludernik, the primacy effect suggests that "what we encounter first in a text will decisively shape our subsequent conceptualizations of the textual world" (idem, "Narratology in the Twenty-First Century: The Cognitive Approach to Narrative," PMLA 125.4 [2010], pp. 924-930). See also Rüggemeier, "Mark's Jesus Reviewed," p. 720; idem, Poetik, pp. 17, 230-231, 408-409.

67 Cf. Rüggemeier, Poetik, pp. 30o-301, 398-40o.

68 As R.B. Hays argues in Echoes of Scripture in the Gospels (Waco: Baylor University Press, 2016), p. 87 . 
the conflation of Ps 2:7 and Isa 42:1 in Mark 1:11). ${ }^{69}$ This case study illustrates how a cognitive approach contributes to central elements of interpretation, rather than simply adding a few nuances.

\section{Character Migration: Recognizing Characters across (New Testament) Stories}

Another aspect of characterization has received almost no attention in biblical studies: character development across more than one narrative. ${ }^{70}$ Some twenty years ago, Umberto Eco noted that "characters migrate."71 Thus, numerous characters leave their original story world also to become inhabitants of later works and narratives. For example, Sherlock Holmes is not only a fictional private detective created by British author Sir Arthur Conan Doyle, but also the protagonist of а ввС series of the same name (broadcasted 2010-2017). The phenomenon of character migration, however, is not only a postmodern one. Antigone, Remus and Romulus, Don Juan, and Faust are earlier examples of such transworld characters. ${ }^{72}$

Considering the numerous characters that "wander" among different New Testament texts, the neglect of character migration in biblical studies is surprising. One immediately thinks of characters like the woman who anoints Jesus ${ }^{73}$ the royal official's son, ${ }^{74}$ Mary Magdalene or Peter. The number

69 E. Shively, "Putting Mark's Passion Narrative in Context," Paper presented at the Annual Meeting of the SBL. San Diego. November 252019.

70 See, however, Merenlahti, Poetics, pp. 85-88 (Judas), 94-97 (Syrophoenician woman), who refers to the trans-narrative development of characters from an author-centred perspective.

71 U. Eco, On Literature (trans. M. McLaughlin; New York: Harcourt, 2005), p. 8.

72 In literary studies, quite different terms have become established to describe the phenomenon of character migration. While L. Doležel and T.G. Pavel were the first to coin the term transworld identity, U. Margolin speaks of itinerant (transworld) individuals or simply of versions. Media and film studies prefer the term transtextual or transmedial characters to emphasize the aspect of medial transition. Cf. L. Doležel, Heterocosmica. Fiction and Possible Worlds (Baltimore and London: Johns Hopkins University Press, 1998); T.G. Pavel, Fictional Worlds (Cambridge and London: Harvard University Press, 1986), p. 36; U. Margolin, "Individuals in Narrative Worlds: An Ontological Perspective," Poetics Today 11.4 (1990), pp. 843-871; idem, "Characters and Their Versions," in C.-A. Mihăilescu and W. Hamarneh (eds.), Fiction Updated: Theories of Fictionality, Narratology, and Poetics (Toronto: University of Toronto Press, 1996), pp. 112-132; B. Richardson, "Transtextual Characters," in J. Eder, F. Jannidis, and R. Schneider (eds.), Characters in Fictional Worlds. Understanding Imaginary Beings in Literature, Film and Other Media (Berlin and New York: De Gruyter, 2010), pp. 527-541; W. Wunderlich, "Cenerentola Risen From the Ashes. From Fairy-Tale Heroine to Opera Figure," in Characters in Fictional Worlds, pp. 542-567. Mark 14:3-11; Matt. 26:6-13; Luke 7:36-5o; John 11:2 and 12:1-8.

74 Matt. 8:5-13; Luke 7:1-10; John 4:46-54. 
of migration characters increases significantly when we include the noncanonical Gospels, the apocryphal Acts, and other early Christian writings. ${ }^{75}$

Scholars initially attempted to explain the reoccurrence of characters diachronically by tracing the history of NT accounts. Influenced by literary studies, this view has been challenged since the early 1990s, when scholars started to explain the similarities between John and the Synoptic gospels as deliberate intertextuality. ${ }^{76}$ The problem with both approaches (i.e., diachronic and intertextual) is that they pay too little attention to the peculiarities of literary characters and primarily focus on verbatim repetitions. From a cognitive science perspective, it is, however, rather unlikely that readers recognize characters primarily by textual reminiscences. Unless they are prominently placed, individual words and phrases are among the most ephemeral components of a text and the reader immediately forgets them. Most likely, today's film audience has only little knowledge of Doyle's original short stories and novels, but still recognizes Sherlock.

\section{The Reader's Recognition of Migration Characters}

In literary studies, the view has prevailed that migration characters are recognized by "a set of core of properties ascribed to the figure in all the works in which it occurs and considered essential to it." ${ }^{\prime 7}$ Thus, Sherlock is identified by his deer-stalker hat, his pipe, and his sharp mind. ${ }^{78}$ Often two or three traits are enough for a doubtless identification.

75 Quite often migration characters even wander between different media, as becomes apparent not only with the example of Sherlock. Thus, early Christian art should necessarily be included in a comprehensive examination of migration characters.

76 In particular, the Louvain School, which presupposes that John and his readers were familiar with the Synoptic Gospels (or at least with Mark), has gained major influence: See H. Thyen, Das Johannesevangelium (HNT, 6; Tübingen: Mohr Siebeck, 2005); idem, "Die Erzählung von den bethanischen Geschwistern (Joh 11,1-12,19) als 'Palimpsest' über synoptischen Texten," in F. van Segbroeck et al. (eds.), The Four Gospels 3 (BETL, 10o; Leuven: Peeters, 1992), pp. 2021-2050.

77 Margolin, "Character," p. 70.

78 Following the lines of a cognitive approach to characters one has to emphasize here that basically all traits, whether mediated explicitly or implicitly, are of relevance. The only decisive factor is whether the recipient pays attention to these traits. The attention drawn to a character trait may be increased by certain techniques of characterization (e.g., repetition, use of foil characters, or primacy effect). For these and other factors that attract attention, see Finnern and Rüggemeier, Methoden, pp. 202-203. 
This does not sufficiently explain, however, why characters remain recognizable despite serious transformations. ${ }^{79}$ This only becomes understandable when characters are perceived as mental models, as defined above. The flexibility of a mental model best explains why readers recognize known characters despite all modifications, revisions, variations, adaptions or Fortschreibungen.

Thinking of Peter, Mary, and others as migration characters holds at least five potentials for New Testament studies. First, this approach increases awareness of the cross-links among the four canonical Gospels, lost due to increasing specialization and one-sided disputes about literary dependencies. ${ }^{80}$ Second, it becomes clearer on a methodological level that there is actually no intertextuality in the strict sense. That is, narratives are "always already" placed in a broader cultural context and within a specific linguistic community. Therefore, it is actual readers - based on literary, cultural, and (possibly) historical knowledge $^{81}$ - who create text references and recognizes characters. ${ }^{82}$ This insight helps to thematize references beyond simple quotations. Third, a cognitive view of character migration adds an important aspect to the current discussion around a "grammar of messianism." 83 Imagining characters as mental models will help to better explain the creative processes which underlie the adaption, accentuation, rearrangement, and communication of messianic

79 Cf. R. Saint-Gelais, Fictions transfuges. La transfictionnalité et ses enjeux (Paris: Seuil, 2011), who emphasizes that transformation is as a key element of migration characters. Well known in literary studies is Doležel's typology of character expansion, transposition, and displacement: See Doležel, Heterocosmica, pp. 206-207. Overall, Doležel's typology remains very general and should be more differentiated. However, this is not possible in the context of this contribution. Cf. M.-L. Ryan, "Transficitionality Across Media," in J. Pier and J.A. García Landa (eds.), Theorizing Narrativity (Narratologia, 12; Berlin and New York: De Gruyter, 2008), pp. 385-417 (385).

80 Thus it is striking that there is basically no comparative study that examines the literary adaption and development of NT characters.

81 The identification of historical persons in a narrative is not categorically different from the identification of purely fictional characters. In this case, narratives also refer back to earlier (oral or written) reports about this person.

82 To give but one example we may refer to the parenthetic explanation in John 11:2, by which Mary, the sister of Martha, is identified with the woman who anoints Jesus. Obviously, the narrator's aside neither refers to Luke's nor to Mark's gospel, but rather refers to a broader notion of the woman. This applies even though John 11:2 functions at the same time as an internal prolepsis in the Johannine narrative. Thus, this kind of foreshadowing only works, because the reader is already familiar with the event of Jesus's anointing and is now curious about John's version.

83 M.V. Novenson, The Grammar of Messianism: An Ancient Jewish Political Idiom and Its Users (New York: Oxford University Press, 2017). 
concepts. ${ }^{84}$ Fourth, this approach problematizes an overly strict distinction between canonical and non-canonical texts, because it becomes clear how the apocryphal literature draws its creative and innovative potential from dealing with NT characters. Similar to Sherlock's sister, who is mentioned only once in Doyle's novels but becomes a central figure in several modern adaptations, ${ }^{85}$ New Testament characters also gain importance and individuality in apocryphal literature (e.g. Mary Magdalene). In addition, their biography is often expanded or they appear at new places (e.g. Mark in Egpyt ${ }^{86}$ ) and meet other celebrities of the early Christ movement (e.g. Marcellus ${ }^{87}$ ). Fifth, the multitude of characters wandering among New Testament and early Christian texts raises the question of cultural, historical, and theological conditions and their implications. In contrast to some postmodern narratives, the borrowing of characters certainly cannot be explained or at least limited to the disturbance of aesthetic illusion. It would seem that there is a variety of causes and reasons, ranging from contradictory historical or theological claims to a more personal or literary interest in minor characters and their future fate. An in-depth investigation would have to explore different factors and implications.

\section{Emotions of Characters and the Reader's Ability to Empathize with them}

A story without emotion is not much of a story. Equally important is the reader's ability to feel with fictional characters. This makes it all the more surprising that New Testament scholarship has addressed the emotional impact of characters on the reader only comparatively late and with little methodical reflection. ${ }^{88}$

This obvious neglect can partly be explained by the influences of dialectical and existentialist theologies in the post-war era. While the theological

84 For a first application, see J. Rüggemeier, "Transworld Characters and the Servant(s) in Romans," in M. Lyons and J. Stromberg (eds.), Isaiah's Servants in Early Judaism and Christianity: The Isaian Servant and the Exegetical Formation of Community Identity (wUNT, 2/554; Tübingen: Mohr Siebeck, 2021), pp. 209-242.

85 See, e.g., the 2020 movie "Enola Holmes."

86 According to Mart. Mk 1 the apostles are sent out to evangelize different countries and Mark travels to North Africa and Egypt.

87 See Thomas J. Kraus's contribution on Marcellus and the Acta Petri in this volume.

88 For a similar judgement, see F.S. Spencer, "Getting a Feel for the 'Mixed' and 'Vexed' Study of Emotions in Biblical Literature," in idem (ed.), Mixed Feelings and Vexed Passions. Exploring Emotions in Biblical Literature (RBSt, 9o; Atlanta: SBL Press, 2017), pp. 1-41 (2). 
liberalism of the 19th century, following Friedrich Schleiermacher's notion of Gefühl, at least showed interest in the religious experiences and feelings of the past, Rudolf Bultmann vehemently rejected all such attempts, labeling them as psychologism and subjectivism. ${ }^{89}$ Later attempts to establish a psychological biblical criticism only strengthened already existing animosities. For example, Eugen Drewermann's Tiefenpsychologische Exegese, an application of psychoanalytic insight to biblical texts, has rightly been criticized for lack of a methodical approach, ${ }^{90}$ the incompatibility with traditional exegetical methods, and a therapeutic rather than interpretative interest. ${ }^{91}$ Last but not least, we can simply ascribe it to the prevailing zeitgeist and male dominated discourse that "emotions have been sidelined in [Biblical] interpretation, deemed universal, irrational, bodily, subjective, chaotic, even feminine or childish, and thus of little value to serious exegetical endavors." 92

These different factors help to explain why the "emotional turn"93 - pervading other disciplines, from neuroscience to historical disciplines - has not yet fully reached New Testament studies. Among the slowly increasing number of exegetical works on emotions, a certain focus on the Gospel of Mark is evident. ${ }^{94}$ Besides this, single works on the Gospel of Luke, ${ }^{95}$ the Johannine

89 Cf. M. Leiner, Psychologie und Exegese. Grundfragen einer textpsychologischen Exegese des Neuen Testaments (Gütersloh: Gütersloher Verlagshaus, 1995), pp. 47-52.

90 Quite similar D.A. Kille, Psychological Biblical Criticism (Guides to Biblical Scholarship. Old Testament Series; Minneapolis: Fortress Press, 2001), p. 19: "Psychological criticism is akin to feminist biblical criticism in that it is not so much a method (or even a cluster of method) as it is a way of reading."

91 The most comprehensive critique of Drewermann's approach is still offered by J. Frey, Eugen Drewermann und die biblische Exegese: Eine methodisch-kritische Analyse (wUNT, 2/71; Tübingen: Mohr Siebeck, 1995).

92 K.M. Hockey, "The Missing Emotion: The Absence of Anger and the Promotion of Nonretaliation in 1 Peter," in Mixed Feelings, pp. 331-353 (332).

93 For an introduction from a historical perspective, see U. Frevert, Emotions in History: Lost and Found (Budapest: Central European University Press, 2011); E. Sullivan, "Review Article: The History of Emotions: Past, Present, Future," Cultural History 2.1 (2013), pp. 93-102.

94 G. Keerankeri, The Love Commandment in Mark. An Exegetico-Theological Study of Mk 12:28-34, (Analecta Biblica, 150; Rome: Editrice Pontificio Istituto Biblico, 2003); D.W. Geyer, Fear, Anomaly, and Uncertainty in the Gospel of Mark (ATLAMs, 47; Lanham and London: Scarecrow, 2002); M. Matjaž, Furcht und Gotteserfahrung. Die Bedeutung des Furchtmotivs für die Christologie des Markus (FB, 91; Würzburg: Echter, 1999); T. Vogt, Angst und Identität im Markusevangelium. Ein textpsychologischer und sozialgeschichtlicher Beitrag (NTOA, 26; Fribourg and Göttingen: Universitätsverlag and Vandenhoeck \& Ruprecht, 1993).

95 A. Inselmann, Die Freude im Lukasevangelium. Ein Beitrag zur psychologischen Exegese (WUNT, 2/322; Tübingen: Mohr Siebeck, 2012). 
Jesus, ${ }^{96}$ and on Paul and the Pauline Letters ${ }^{97}$ have been published. These studies, however, are almost exclusively text-centered. That is, they show a lexical interest by primarily focusing on the explicit mention of single emotions (esp. agápē, phóbos, and chará), which are then interpreted in the wider literary context. ${ }^{98}$ What is needed is a comprehensive methodology for analyzing the variety of narrative means used to convey emotions and to generate empathy, while simultaneously proving compatibility with the historical interests of New Testament exegesis. ${ }^{99}$

Under the influence of cognitive sciences, postmodern narratology has, in contrast, produced a whole range of concrete methodological approaches over the last fifteen years that New Testament interpreters should adopt.

\section{How to Analyze the Emotions of Fictional Characters on the Basis of Cognitive Linguistics}

Ancient and modern literature rarely mention the feelings of a character explicitly. ${ }^{100}$ In most cases, the intended audience inevitably anticipates emotions on the basis of a previous image of a character and the audience's cultural frames and scripts (see above). Thus, the readers might infer emotions

96 S. Voorwinde, Jesus' Emotions in the Fourth Gospel. Human or Divine? (LNTS, 284; London and New York: T\&T Clark, 2005).

97 A. Inselmann, "Zum Affekt der Freude im Philipperbrief. Unter Berücksichtigung pragmatischer und psychologischer Zugänge," in J. Frey and B. Schliesser (eds.), Der Philipperbrief des Paulus in hellenistisch-römischer Welt (wUnT, 353; Tübingen: Mohr Siebeck, 2015), pp. 255-288. On Paul, see T.H. Olbricht and J.L. Sumney, Paul and Pathos (SymS, 16; Atlanta: SBL Press, 2001); D.E. Fredrickson, Eros and the Christ. Longing and Envy in Paul's Christology (Paul in Critical Contexts; Minneapolis: Fortress Press, 2013). For a reflection on Paul's rhetorical use of emotions, see also G.S. Selby, Not with Wisdom of Words. Nonrational Persuasion in the New Testament (Grand Rapids and Cambridge: Eerdmans, 2016).

98 A notable exception to this is T. Dannenmann's work on the Gospel of Matthew, in which she takes a decisive step forward by formulating a comprehensive "emotive heuristics:" Emotion, Narration und Ethik, (wUNT, 2/498; Tübingen: Mohr Siebeck, 2019), esp. pp. 153-221.

Against the background of this desideratum, it is rather astonishing that in one of the more recent volumes on emotions in the Bible - F. Scott Spencer's Mixed Feelings and Vexed Passions - deliberately rejects this precise task. Thus, Spencer states somewhat succinctly that "the following emotionally focused essays stand alone and speak for themselves" (Spencer, "Getting a Feel," p. 3).

100 For ancient narratives this holds even more true, as "in Hebrew and Greco-Roman literature ... information about a character is conveyed primarily through the character's speech and actions rather than the narrator's statements" (Bennema, Theory, p. 56) 
from other character traits during reading, this is to say: a character's behavior, movement, outer appearance, desire, or psychological dispositions. ${ }^{101}$

In her work on lyrical texts around 190o, Simone Winko coined the expression of coded feelings to stress the cultural and temporal embeddedness of emotional expressions and "prototypical emotional actions and situations."102 These actions and situations include culturally standardized behavior known to contemporaries - like the tearing of one's garment in NT times (Mark 14:63 $)^{103}$ - but also more subtle and situational actions, including gestures or a person's way of articulation. For example, when the servant-girl at the courtyard turns to the bystanders, accusing Peter of being one of Jesus' followers (hoũtos ex autõn estin), Peter immediately reacts to her words (ho dè pálin êrneĩto), even though he is not the one addressed. ${ }^{104}$ The intended audience might explain this reaction either by Peter's anxiety and nervousness or as an deliberate attempt to pre-empt the response of the others. In a similar way ancient plays and literature also reflect on speaking styles ${ }^{105}$ and put in scene the conversational behaviour of characters. ${ }^{106}$

Yet when Mark's readers are confronted with Peter's unexpected answer (Mark 14:63), they can also fall back on the previous image of this fictional person. Accordingly, the readers of Mark's Gospel have already known Peter as someone who reacts anxiously in distress (Mark 4:41), does not know

In today's narratology different systematizations for character traits are discussed. For a summary, see S. Finnern and J. Rüggemeier, Methoden der neutestamentlichen Exegese. Ein Lehr-und Arbeitsbuch (utb, 4212; Tübingen: A. Francke, 2016), pp. 198-203.

S. Winko, Kodierte Gefühle. Zu einer Poetik der Emotionen in lyrischen und poetologischen Texten um 1900 (Allgemeine Literaturwissenschaft - Wuppertaler Schriften, 7; Berlin: Schmidt, 2003), p. 131.

In Mark 14:63 this action is probably not only to be understood as an expression of shock and despair (Jos 7:6; Judg 11:35; 1Kings 21:27; 2Kings 19; 2Sam 13:19, but also as reaction towards Jesus's blasphemy (cf. Num 14:6; Ezra 9:3, 5). On the tearing of one's garment, see M. Köhlmoos, “Tearing One's Clothes and Rites of Mourning," in Christoph Berner et al. (eds.), Clothing and Nudity in the Hebrew Bible (London et al.: T\&T Clark, 2019), pp. 303-313 (esp. 312f.).

104 For this fine observation, see Hartvigsen, Prepare the Way, p. 486.

105 Cf. E. van Emde Boas, "Aeschylus," in K. de Temmerman and E. van Emde Boas (eds.), Characterization in Ancient Greek Literature (Studies in Ancient Greek Narrative, 4; Leiden and Boston: Brill, 2017), pp. 317-336 (esp. 330-332), who refers among others to Hesiod, Theog. 182-202 (the chorus's panic reaction); Aeschylus, Ag. 1399 (Clytemnestra's arrogance); 1112-1113, 1152-1153 (Cassandra's mysterious language); Aristophanes, Ran. 911920 (Aeschylus's use of silence).

106 For example, the fact that Cassandra "fails to answer direct questions (e.g. [Ag.] 1119-1126, 1150-1161)" or remains silent for a long period of time (30o lines) "invite audience members to construct an explanation for Cassandra's behaviour ..." (van Emde Boas, "Aeschylus," p. 331). 
what to answer when he is frightened (Mark 9: ${ }^{107}$ ), and repeatedly breaks in (Mark 8:32;14:31). The readers are thus able to integrate Peter's behavior at the courtyard into the previous character model. ${ }^{108}$ We can generalize this short example: the analysis of emotions should always keep both in mind, the coded feelings of the the intended audience (derived from historical sources) and the overall image of a character (evoked by the narrative).

\section{How to Analyze Empathy on the Basis of Cognitive Linguistics}

Empathy is the ability of a person to show solidarity with the fate of others and to relate ${ }^{109}$ to other people's emotions. We retain this capacity for empathy in our encounters with fictional characters. ${ }^{110}$ At the same time, however, one can put a book aside and distance oneself from what is being told in a different way than from real events. ${ }^{111}$ This possibility of distancing can be favored by the reader's temporal and spatial distance from the narrative world or the reader's increased knowledge. When Peter and the other disciples obviously fear for their lives, because "the waves break over their boat, so that it is nearly swamped" (Mark 4:37), the intended audience understands this reaction, but at the same time will critically distance from this behavior. From the readers' post-Easter perspective, it would be absurd to assume that Jesus could abandon his disciples. From the readers' point of view it is understandable why the Markan Jesus equates the disciples' fear with unbelief (Mark 4:40: oúpō ékhete pístin).

As in this example, readers are generally not bound to the subjective viewpoint of a character, but are able to predict a character's fate beforehand. Thus, one may fear for a fictional person who does not yet know the danger

107 See the narrator's own comment: (He did not know what to answer for they were afraid).

108 On the coherence of Markan character portraits, see Rüggemeier, Poetik, pp. 222-307.

109 In literary studies it is a matter of ongoing debate whether empathy must necessarily be a "feeling" or whether it can be considered as a predominantly cognitive process. Cf. K. Mellmann, "Gefühlsübertragung? Zur Psychologie emotionaler Textwirkungen," in I. Kasten (ed.), Machtvolle Gefühle (Berlin and New York: De Gruyter, 2010), pp. 107-119 (115-116).

$110 \quad$ "Readers by default assume that they will encounter real-life characters and make a concerted effort to fill in the schematic gaps to produce human-like constructs." (M. Bortolussi and P. Dixon, Psychonarratology. Foundations for the Empirical Study of Literary Response [Cambridge: Cambridge University Press, 2003], p. 152).

111 Cf. F. Zipfel, "Emotion und Fiktion. Zur Relevanz des Fiktions-Paradoxes für eine Theorie der Emotionalisierung in Literatur und Film, in S. Poppe (ed.), Emotionen in Literatur und 
or rejoice with a character unaware of their own luck. Under the influence of neuroscientific insights, a distinction between "feeling with" and "feeling for" 12 has become established in literary studies; the first expression referring to the reader's affective sharing of a fictional person's feelings (empathy), the latter to the reader's ability to slip into the role of a rather distanced observer (sympathy).

Another aspect that is essential for narrative analysis is determining the actual degree of empathy a reader develops towards a character. As empirical studies reveal, ${ }^{113}$ the reader's empathy cannot simply be equated with the internal perspective. ${ }^{114}$ Other aspects regarding the narrative situation have to be taken into account as well. ${ }^{115}$ Furthermore, the development of empathy is fostered by different techniques of characterization. Thus, individual, mysterious, and complex characters, who are defined by a multitude of explicit or implicit traits, ${ }^{116}$ and main characters ${ }^{117}$ rather attract the reader's attention and make them easier to empathize with. Similarities between the character and the reader or between the character and a person known to the reader

Film (Film - Medium - Diskurs, 36; Würzburg: Königshausen \& Neumann, 2012), pp. 127154 (150), who uses the expression "Probefühlen" (sample feeling) in this context.

This is also emphasized by V. Barthel, Empathie, Mitleid, Sympathie. Rezeptionslenkende Strukturen mittelalterlicher Texte in Bearbeitungen des Willehalm-Stoffs (Quellen und Forschungen zur Literatur- und Kulturgeschichte, 5o; Berlin and New York: De Gruyter, 2008), p. 39: "während Empathie unabhängig davon funktioniert, ob das Gegenüber geschätztes Vorbild oder gehasstes Feindbild ist, verlangt Sympathie zusätzlich Wertschätzung, also eine positive Einstellung zum Gegenüber."

113 W. Van Peer and H. Pander Maat, "Narrative Perspective and the Interpretation of Characters' Motives," Language and Literature 10.3 (2001), pp. 229-241. Cf. also Jannidis, Figur, pp. 232-234.

114 For a long time this equation has almost been a "commonplace of narrative theory" (Suzanne Keen, Empathy and the Novel [Oxford: Oxford University Press, 2007], p. 96). The guarantor for this thesis is W. Booth, The Rhetoric of Fiction (Chicago: University of Chicago Press, 2nd edn, 1983), pp. 377-378. Biblical scholars also followed this view: see, e.g., J.-L. Ska, Our Fathers Have Told Us. Introduction to the Analysis of Hebrew Narratives (SubBi 13; Rome: Pontificio Istituto Biblico, 199o), p. 91; S.H. Smith, A Lion with Wings. A Narrative-Critical Approach to Mark's Gospel,(BibSem 39; Sheffield: Sheffield Academic Press, 1996), p. 57.

115 See Suzanne Keen, "A Theory of Narrative Empathy," Narrative 14.3 (2006), pp. 207-236 (216), who refers to the person of the narration, the implicit location of the narrator, the relation of the narrator to the characters, and the internal or external perspective on characters.

116 See Eder, Figur im Film, p. 229.

117 Still, as Keen, "Theory," p. 218, emphasizes, one must not "preclude empathetic response to flat characters, minor characters, or stereotyped villains and antagonists." Also the biographical, ethnic, or social background of a reader can promote empathy with individual minor characters. Cf. Keen, Empathy, pp. 93-96. 
increase this effect. ${ }^{118}$ In addition, the reader pays more attention to characters if the narrator or other characters (repeatedly) comment on them and their behavior or fate. ${ }^{119}$ Beyond this, a variety of other elements have been associated with empathetic effects, ${ }^{120}$ including "genre expectations, vivid use of settings, metanarrative commentary, and aspects of the discourse that slow readers' pace (foregrounding, uses of disorder, etc.)."121

\section{How to Analyze Sympathy ${ }^{122}$ on the Basis of Cognitive Linguistics}

Though empathy often leads to sympathy and the degree of empathy influences the degree of sympathy (or antipathy), the ability to understand a character's inner state and its evaluation remain two different aspects. While empathy refers to the reader's cognitive and emotional engagement with a character, sympathy can be defined as a consenting agreement with a character. Sympathy implies that the reader approves of the thinking, feeling, acting of a character. This does not necessarily mean, however, that the reader themselves shares the same characteristics or is able to act accordingly. I can sympathize with Jesus driving out demons without being able to imitate him. The evaluation of a character's behavior is based on a) culturally mediated norms (e.g. Lev 19:9-18) or the norms of the audience (e.g. Mark 7:19) and can additionally be influenced by b) narrative asides (e.g., Mark 6:52), c) the comments of other (reliable) characters (e.g., Mark 8:17), d) a character's fate (e.g., Mark 14:50), e) the use of foil characters (e.g., Mark 14:50 vs. 15:40-41), and of the use/ influence of culturally mediated stereotypes (a priest, a Levite, a Samaritan). ${ }^{123}$

\section{Conclusion and Synopses}

We addressed four aspects of character analysis that seem particularly promising for New Testament exegesis: characterization, character development,

\footnotetext{
118 See Keen, “Theory," pp. 214-219; cf. Keen, Empathy, pp. 93-96.

119 Eder, Figur im Film, pp. 678-68o.

120 See Keen, "Theory," pp. 215-216.

121 Keen, "Theory," p. 216.

122 For further methodological reflection, see Eder, Figur im Film, pp. 669-673; Barthel, Empathie, pp. 39-41, 66-72; Booth describes various strategies employed by Austen, Dickens, Joyce, Porter, and others: Booth, Rhetoric of Fiction, pp. 129-133, 243-266, 274-282, 379-391.

123 For more details on these criteria, see Schneider, Grundriß, pp. 116-127 (esp. 125-126); Jannidis, Figur, pp. 234-235.
} 
character migration, character emotions. Other aspects of analysis still require attention, including the relation of character to meaning, ${ }^{124}$ Genre (expectations), ${ }^{125}$ plot, ${ }^{126}$ and movement and space. ${ }^{127}$ Nevertheless, we have demonstrated how the cognitive turn has led to a considerable analytical gain, which remains to be perceived sufficiently within our discipline.

The following contributions apply the analytical aspects we have introduced and extend them with further methodological approaches.

Cornelis Bennema shows how the reader's literary and social knowledge affects the construction of characters. For this purpose, he sets up four distinct readers, each with a different level and extent of knowledge and examines the account of Peter's calling in all four canonical Gospels. By this approach he proposes a plausible account of how readers arrive at different constructions of the very same character.

Michael R. Whitenton demonstrates the interpretive and analtytical advantages of a blending-based approach to New Testament characters. He examines the changes in Nicodemus's love over all three appearances in the Gospel of John (John 3, 7, 19). Modeling Nicodemus in terms of input space integration and backward projection allows Whitenton to account more fully for the dynamics of character reception by explaining the "mechanics" behind the reader's continous reconfiguration and reassesment of Nicodemus. Moreover, Whitenton's inclusion of both literary and real-world frames helps us to understand how different mental constructions of the same character emerge, but also to evaluate these different versions.

124 On the conveyance of meaning through characters, see Eder, Figur im Film, pp. 713-716 (character as fictional being), $716-719$ (characters as artifacts), $722-724$ (character as symbol and symptom).

125 On a cognitive approach to Mark's genre and implications for the narrative, see E.E. Shively, "Recognizing Penguins: Audience Expectation, Cognitive Genre Theory, and the Ending of Mark's Gospel." Catholic Biblical Quarterly 8o (2018): 273-292. See further idem., "A Critique of Richard Burridge's Genre Theory: Shifting from a One-Dimensional to a MultiDimensional Approach to Gospel Genre." Pages 97-112 in R.M. Calhoun; D.P. Moessner; T. Nicklas (eds.). Modern and Ancient Literary Criticism of the Gospels. Continuing the Debate on Gospel Genre(s). WUNT I 451; Tübingen: Mohr Siebeck, 2020.

126 Superficially, plot is perceived as a sequence of factual events and event structures. Cognitive linguistics expands this view by also considering potential or "virtual" events evoked in the reader's mind by characters and their behaviour. Cf. Ryan, Possible Worlds, pp. 157-161. For a methodological reflection and a possible application to New Testament texts, see Finnern and Rüggemeier, Methoden, pp. 219-222; Rüggemeier, Poetik, pp. 86-89. On the character and space connection, see J. Rüggemeier, "Ein See, zwei Ufer. Raum und erzählte Welt im Markusevangelium," in C. Bartsch and F. Bode (eds.), Welt(en) erzählen: Paradigmen und Perspektiven (Narratologia, 65; Berlin and Boston: De Gruyter, 2019), pp. 317-339. 
Bonnie Howe and Eve Sweetser present a fresh reading of the Parable of the Good Samaritan (Luke 10:25-37). In their interpretation, they employ various cognitive-linguistic models to map out how contemporary readers understand and interpret the parable's characters. They base their argument on the cognitive-linguistic concept of "ground," use semantic frames, and attend to Luke's narrative embedding of the parable. As a result, Howe and Sweetser show how an understanding across the historical and cultural distance of nearly 2000 years is still possible.

Kirsten Hartvigsen also shows the advantage of a blending-based approach to character construction in Luke $1-2$. She notes that the plot of the narrative emphasizes the main characteristics of two couples and their sons, which then accentuates key characteristics of God. She performs a textual analysis with insights into mental character models and social schemata. The first part of her analysis consists of a linear presentation of information in orally performed narratives structures. In the second part, she draws on conceptual blending theory to explore how the character of God is constructed based on selected information projected from the utterances of the other characters to the blend space.

Thomas J. Kraus shows how the reader of the apocryphal Acts of Peter is invited to identify with the Roman senator Marcellus, one of the three main characters of the narrative (besides Peter and Simon Magus). Based on the approach of cognitive narratology, he draws attention to the active role of the reader, who draws on their prior reading knowledge and real-world frames to flesh out the character of Marcellus and to trace his development over the course of the story. It is precisely the individual traits of Marcellus and his development from a generous but initially still wavering Roman senator to a steadfast follower of Jesus that invite the reader to identify with this character.

Finally, we have invited response articles from three guests outside the discipline of biblical studies who use cognitive disiplines in their scholarship. The purpose of this exercise is to expand our interdisciplinary dialogue and insights: Suzanne Keen, "Ancient Characters and Contemporary Readers: A Response to Jan Rüggemeier \& Elizabeth E. Shively and Cornelis Bennema;" Ralf Schneider, "Potential and Actual Cognitive-Emotional Engagement with Characters: A Response to Michael R. Whitenton and Bonnie Howe \& Eve Sweetser;" and Evert van Emde Boas, "Emotion, Memory, Meaning, Directions: A Response to Kirsten Marie Hartvigsen and Thomas J. Kraus." 